\title{
ANALISIS KINERJA SUPPLY CHAIN MANAGEMENT BERBASIS BALANCED SCORECARD PADA PT. ALOVE BALI IND
}

\author{
Dannis Tanaka ${ }^{1}$ \\ I Nyoman Nurcaya ${ }^{2}$ \\ ${ }^{1,2}$ Fakultas Ekonomi dan Bisnis Universitas Udayana (Unud), Bali, Indonesia \\ e-mail: danniskyu@yahoo.com
}

\begin{abstract}
ABSTRAK
Tujuan penelitian ini adalah untuk mengetahui apakah kinerja supply chain management suatu perusahaan sudah terlaksana dengan baik dilihat dari keempat perspektif balanced scorecard. Penelitian ini dilakukan di PT. Alove Bali IND. Jumlah sample yang diambil sebanyak 20 karyawan PT. Alove Bali IND serta 5 agen PT. Alove Bali IND, Pengumpulan data dilakukan melalui penyebaran kuesioner dan wawancara. Teknik analisis data yang digunakan menggunakan pendekataan balanced scorecard. Berdasarkan hasil analisis ditemukan bahwa Kinerja PT.Alove Bali IND diukur malalui perspektif keuangan kurang baik dikarenakan masih terjadi fluktuatif di tahun 2012 hingga tahun 2014 dan dalam menjalankan operasionalnya perusahaan masih sangat tergantung oleh hutang. Pada perspektif pelanggan kinerja perusahaan sudah terbilang baik dikarenakan nilai rata-rata keselurahan responden adalah sebesar 4.20. Pada perspektif bisnis internal kinerja perusahaan sudah terbilang sangat baik dikarenakan nilai ratarata keselurahan responden adalah sebesar 4.78. Pada perspektif Pembelajaran dan pertumbuhan kinerja perusahaan sudah terbilang sangat baik dikarenakan nilai rata-rata keselurahan responden adalah sebesar 4.61.
\end{abstract}

Kata kunci: supply chain management, balanced scorecard, manajemen operasi

\begin{abstract}
The purpose of this study is to determine whether the performance of a company's supply chain management has been done well viewed from. This research was conducted at PT. Alove Bali IND. The number of samples taken as many as 20 employees of PT. Alove Bali IND and 5 agents PT. Alove Bali IND, Data collection is done through questionnaires and interviews. Data analysis techniques used to use. Based on the results of the analysis that has been found, PT.Alove Bali IND Regarding Changes malalui financial perspective is not good due to fluctuating in the year 2012 until 2014 and in running its operations the company is still very dependent by debt. On the perspective of the company's performance of the company has been fairly good physical average of all respondents is 4.20. On the internal business perspective the company's performance has been very good. On the perspective of learning and performance growth of the company has been very good because the average of all respondents is 4.61.
\end{abstract}

Keywords: supply chain management, balanced scorecard, operation management 


\section{PENDAHULUAN}

Persaingan dunia bisnis yang semakin ketat, membuat perusahaan harus mencari cara dalam menjalankan bisnisnya secara efisien dan menjalankan strategi yang tepat dalam mengatasi lingkungan yang terjadi (Lestari, 2015). Persaingan pun semakin kompleks karena munculnya pesaing baru. Satu-satunya cara agar tidak terpuruk dalam persaingan adalah meningkatkan daya saing perusahaan dengan strategi yang tepat. Upaya yang dapat dilakukan diantaranya peningkatan efektifitas dan efisiensi, perbaikan dalam proses operasional, dan peningkatan kualitas. Ketika seluruh proses operasional perusahaan berjalan baik maka akan mampu menghasilkan produk yang unggul dan kompetitif.

Dunia bisnis sekarang ini terus bersaing untuk menciptakan berbagai kebutuhan konsumen yang semakin tinggi, dan semakin cerdas dalam memilih kebutuhannya. Setiap perusahaan akan berupaya semaksimal mungkin untuk meningkatkan produktivitas, efisiensi, pelayanan yang cepat, mudah dan terus menciptakan berbagai inovasi-inovasi baru untuk tetap dapat unggul dan bertahan di pasar (Ariani dan Munas, 2013). Menurut Widyanto (2012), pada dasarnya konsumen mengharapkan dapat memperoleh produk yang memiliki manfaat pada tingkat harga yang dapat diterima. Untuk mewujudkan keinginan konsumen, maka setiap perusahaan berusaha secara optimal untuk menggunakan seluruh asset dan kemampuan yang dimiliki untuk memberikan value terhadap harapan konsumen. Implementasi upaya ini tentunya menimbulkan kosekuensi biaya yang berbeda di setiap perusahaan termasuk para pesaingnya. Untuk dapat menawarkan produk yang menarik dengan tingkat harga yang 
E-Jurnal Manajemen Unud, Vol. -, No. -,2018:

bersaing, setiap perusahaan harus berusaha menekan atau mereduksi seluruh biaya tanpa mengurangi kualitas produk maupun standar yang sudah ditetapkan. Salah satu upaya untuk mereduksi biaya tersebut dengan melalui optimalisasi distribusi material dari pemasok, aliran material dalam proses produksi sampai dengan ditribusi produk ke tangan konsumen. Distribusi yang optimal dalam hal ini dapat dicapai melalui penerapan konsep Supply Chain Management. Sejalan dengan Ramanathan (2011) bahwa perusahaan saat ini tidak hanya terlibat dalam aktivitas internal mereka seperti produksi dan distribusi, namun juga terlibat dalam kolaborasi supply chain dengan mitra mereka. Manajemen rantai pasokan merupakan bagian penting dalam kegiatan perusahaan saat ini. Jadi dapat disimpulkan bahwa bisnis yang terjadi zaman sekarang bukan lagi bisnis antara perusahaan secara individu melainkan persaingan bisnis secara jejaring, yang artinya kompetisi yang terjadi adalah terkoordinasinya suatu bisnis dalam jejaring di suatu rantai pasokan.

Supply Chain Management merupakan pendekatan untuk mengoptimalkan integerasi antara supplier, manufaktur, gudang dan penyimpanan, sehingga produksi dan distribusi barang dapat dilakukan dalam jumlah yang tepat, lokasi yang tepat, waktu yang tepat serta meminimalisir biaya dan memberikan kepuasan layanan terhadap konsumen (Widyanto, 2012). Supply Chain Management mencakup kegiatan yang lebih kompleks daripada hanya sekedar pengendalian sistem logistik. Supply Chain Management yaitu manajemen aktivitas pengadaan barang dan pelayanan, pengubahan menjadi barang setengah jadi dan produk akhir, serta pengiriman melalui sistem distribusi (Heizer dan Render, 2005:4 ). 
Dannis Tanaka dan I Nyoman Nurcaya, Analisis Kinerja...

Untuk menjalankan praktek supply chain management yang baik terdapat beberapa faktor penting seperti adanya information sharing, long term relationship, cooperation dan juga process integration. Dengan adanya information sharing yang akurat akan mempercepat proses kegiatan supply chain management dari supplier hingga ke tangan konsumen akhir, sedangkan hubungan jangka panjang dapat tercipta dengan adanya hubungan yang berkesinambungan antara semua pihak yang terlibat di dalam jaringan suatu supply chain management dan dengan kerjasama (cooperation) yang baik yang saling menguntungkan antara semuapihak tentu hubungan jangka panjang tersebut dapat tercapai. Sedangkan process integeration merupakan penggabungan dari semua kegiatan supply chain management agar seluruh kegiatan berjalan dengan lancar.

Pada penelitian Rachbini (2016) menemukan hasil bahwa faktor penting dalam supply chain management sepeti information sharing, cooperation dan process integration berpengaruh positif terhadap kinerja perusahaan namun hubungan jangka panjang (long term relationship) berpengaruh negatif terhadap kinerja perusahaan, dengan menerapkan information sharing, cooperation dan process integration yang baik dapat mengabaikan hubungan jangka panjang. Berbeda halnya dengan penelitian Aziz dan Dwiyanto (2017) yang mendapat hasil information sharing, long term relationship dan process integration berpengaruh positif terhadap kinerja supplly chain management namun cooperation berpenagruh negatif terhadap kinerja supply chain management. 
Menurut Pujawan (2010), manajemen rantai pasokan (supply chain management) menjadi salah satu strategi penting dalam membangun keunggulan bersaing organisasi dan perusahaan. Wagner, et al. (2012) menyatakan semakin perusahaan mampu mengelola supply chain dengan baik maka Return Of Assets (ROA) perusahaan akan semakin tinggi. Ini berarti bahwa supply chain management mampu mempengaruhi kinerja keuangan suatu perusahaan ini dibuktikan oleh beberapa penelitian seperti S. Suzuki, et al. (2009), A. Ellinger, et al. (2011), Shi and Yu (2013), D’Avanzo and Lewenski (2003) yang mengatakan bahwa supply chain management mampu meningkatkan kinerja keuangan suatu perusahaan.

Pada kinerja keuangan, supply chain management juga memiliki beberapa manfaat lainnya seperti pada penelitian Rahmasari (2011) dan Thatte, et al. (2013) yang menyatakan bahwa praktek supply chain management berpengaruh positif terhadap kinerja perusahaan dan keunggulan bersaing. Penelitian Suharto dan Devie (2013) menyatakan penerapan supply chain management yang baik mampu meningkatkan kinerja perusahaan, baik kinerja keuangan maupun operasional. Bukan hanya pada kinerja perusahaan dan keunggulan bersaing saja namun juga penerapan dari supply chain management yang baik mampu mempertahankan loyalitas daripada pelanggan (Ruslim, 2013)

Aktivitas manajemen rantai pasok yang mencakup mulai dari pemenuhan pasokan barang dari pemasok ke manufaktur sampai ke pemenuhan order dari pelanggan. Tanpa manajemen rantai pasok, tidak ada produk. Tanpa produk, tidak ada order penjualan yang bisa dipenuhi. Tanpa ada penjualan, perusahaan tidak mungkin 
dapat beroperasi secara normal. Dapat disimpulkan bahwa tulang punggung sebuah organisasi adalah supply chain management. Dimana efektivitas strategi supply chain management yang diterapkan mencakup pasar efektif, dan ketersediaan produk yang memegang kunci untuk pendapatan sebuah perusahaan. Penurunan minat dan permintaan konsumen berasal dari kesalahan setiap produksi dan ketidaktersediaan produk pada waktu yang tepat yang dapat menyebabkan bencana bagi organisasi.

Pengukuran kinerja adalah salah satu faktor yang penting bagi organisasi bisnis. Pada sistem pengendalian manajemen dalam suatu organisasi bisnis, pengukuran kinerja adalah usaha yang dilakukan oleh pihak manajemen untuk mengevaluasi hasil kegiatan yang telah dilaksanakan oleh pusat pertanggungjawaban (Widyanto dalam Tansri, 2012). Untuk itu, pengukuran kinerja sangat dibutuhkan agar dapat membangun sebuah perencanaan maupun pengendalian untuk mencapai visi dan misi sebuah orgaisasi. Tentu saja pengukuran kinerja supply chain management harus sangat diperhatikan dilihat dari betapa pentingnya pengaruh dari supply chain tersebut terhadap perusahaan.

Balanced scorecard adalah sebuah gagasan yang diciptakan untuk menyeimbangkan aspek keuangan dan non keuangan. Menurut Hansen dan Mowen (2009), Balanced scorecard adalah sebuah sistem manajemen kinerja yang terintegrasi yang menghubungkan berbagai tujuan, ukuran kinerja dan strategi sebuah organisasi. Balanced scorecard menerjemahkan misi dan visi organisasi kedalam tujuan organisasional dan ukuran kinerja kedalam empat perspektif, yaitu perspektif pelanggan, perspektif keuangan, perspektif proses bisnis internal, serta perspektif 
E-Jurnal Manajemen Unud, Vol. -, No. -,2018:

pembelajaran dan pertumbuhan (Hansen dan Mowen, 2009:366). Balanced Scorecard merupakan alat yang cocok untuk mengevaluasi dan merancang strategi operasi (Dodangh, 2010). Menurut Wibowo (2006), Balanced Scorecard mampu menerjemahkan strategi ke dalam sebuah proses yang bukan hanya menjadi milik manajemen puncak, namun juga setiap individu pada setiap level perusahaan.

PT Alove Bali IND merupakan sebuah perusahaan manufaktur yang beralamat di Banjar Tengah Bonbiyu, Desa Saba, Kecamatan Blahbatuh, Kabupaten Gianyar. Perusahaan ini didirikan pada tahun 2003 oleh investor dari Belanda. PT Alove Bali IND dari tahun 2008 hingga 2010 hanya memproduksi ekstrak lidah buaya. Namun tahun 2011, perusahaan beralih memproduksi pupuk cair organik yang berbahan dasar lidah buaya (aloe vera). Produk utama pada PT. Alove Bali adalah pupuk organik cair yang berbahan dasar lidah buaya dengan merek SUNLAND. Pupuk SUNLAND sendiri sangat bermanfaat untuk menyuburkan tanah, meningkatkan pertumbuhan, menguatkan perakaran, serta meningkatkan hasil produksi.

Pupuk organik SUNLAND dipasarkan baik dalam negeri maupun luar negeri. untuk pupuk organik ini PT. Alove Bali hanya memproduksi 500.000 liter tiap bulannya. Selain pupuk organik SUNLAND PT. Alove Bali juga memproduksi produk setengah jadi berupa gel lidah buaya. Dari hasil wawancara peneliti terhadap salah satu manajer PT. Alove Bali bahwa perusahaan pada tahun 2012 dan 2014 mengalami kerusakan produk dan menyebabkan penjualan dari tahun 2012 mengalami pasang surut akibat kerusakan produk ini. Maka dari itu perlu adanya upaya untuk mengetahui 
penyebab dari kerusakan produk ini dimana kerusakan produk ini dapat dimasukkan ke dalam perspektif bisnis internal di dalam balanced scorecard pada supply chain management.Berdasarkan latar belakang masalah yang telah dibahas, maka dapat dirumuskan permasalahan dalam penelitian ini adalah : Apakah kinerja rantai pasokan pada PT. Alove Bali sudah terlaksana dengan baik.

\section{TELAAH LITERATUR DAN HIPOTESIS PENELITIAN}

\section{Pengertian Supply Chain}

Supply chain adalah dapat diartikan sebagai jaringan perusahaan yang bekerjasama sebagai pencipta dan penghantar produk ke tangan konsumen akhir. Perusahaan-perusahaan tersebut biasanya termasuk supplier, pabrik, distributor, toko, atau ritel, serta perusahaan-peusahaan pendukung seperti perusahaan logistik (Pujawan, 2010:5)

\section{Supply Chain Management}

Menurut Jay Heizer dan Barry Render (2010:4), Supply Chain Management (SCM) adalah integrasi aktivitas pengadaan bahan dan pelayanan, pengubahan menjadi barang setengah jadi dan produk akhir, serta pengiriman ke pelanggan. Manajemen rantai pasokan yang efektif menjadikan para pemasok sebagai "mitra" dalam strategi perusahaan untujk memenuhi pasar yang selalu berubah. Suatu keunggulan bersaing dapat bergantung pada hubungan strategis jangka panjang yang dekat dengan sedikit pemasok.

Menurut Pujawan (2010:24), Supply Chain Management (SCM) adalah metode atau pendekatan integratif untuk mengelola aliran produk, informasi, dan 
E-Jurnal Manajemen Unud, Vol. -, No. -,2018:

uang secara terintegrasi yang melibatkan pihak-pihak mulai dari hulu ke hilir yang terdiri dari supplier, pabrik, jaringan distribusi maupun jasa-jasa logistik

\section{Kinerja Supply Chain Management}

Kinerja adalah hasil akhir ataupun pencapaian dari semua kegiatan perusahaan dalam satu periode untuk mewujudkan tujuan, sasaran, visi dan misi perusahaan tersebut.

\section{Pengertian Balanced Scorecard Sebagai Metode Penilaian Kinerja}

Balanced scorecard dikaitkan dengan kartu skor. Kartu skor dapat digunakan untuk mencatatat hasil kinerja seseorang yang telah diskor. Kartu ini dapat digunakan untuk merencanakan skor yang ingin diwujudkan personel kedepannya sehingga skor yang hendak diwujudkan oleh personel dapat dibandingkan dengan kinerja sesungguhnya. Balanced Scorecard adalah sebuah alat manajemen untuk menghubungkan antara tindakan bisnis berdasarkan visi, misi dan strategi organisasi secara seimbang yang kemudian dapat diterapkan dalam organisasi tersebut.

\section{Perspektif Balanced Scorecard}

\section{Perspektif Keuangan}

Ukuran kinerja keuangan menunjukkan apakah strategi, implementasi dan eksekusi dari suatu perusahaan secara efektif berkontribusi terhadap peningkatan tujuan keuangan, termasuk pencapaian profability, menjaga likuiditas dan solvabilitas baik jangka pendek maupun jangka panjang, pertumbuhan omset penjualan dan memaksimalkan kekayaan pemegang saham (Bhagwat \& Sharma, 2007). 


\section{Perspektif Pelanggan}

Dalam perspektif pelanggan ukuran kinerja ditujukan untuk menciptakan hasil yang nyata bagi pelanggannya. Menurut (Yuwono, dkk., 2006:32), filosofi manajemen terkini telah menunjukkan peningkatan pengakuan atas pentingnya customer focus dan customer satisfaction. Perspetif ini merupakan leading indicator. Perspektif pelanggan memiliki dua kelompok pengukuran yakni customer core measurenment yang berhubungan dengan market share, customer retention, customer acquisition, customer satisfaction, customer profitability, serta customer value proposition yang berhubungan dengan product/service attributes, customer relationship, dan image and relationship.

\section{Perspektif Bisnis Internal}

Perusahaan harus memutuskan proses apa yang harus mereka pimpin dan menentukan langkah yang tepat untuk mereka (Bhagwat \& Shamar, 2007). Dimulai dengan penerimaan pesanan pelanggan dan diakhiri dengan pengiriman produk ke pelanggan (Kaplan \& Norton, 1996). Scorecard memungkinkan manajer agar dapat mengetahui seberapa baik bisnis perusahaan berjalan dan apakah produk atau jasanya sesuai dengan spesifikasi pelanggan.

\section{Perpsektif Pembelajaran dan Pertumbuhan}

Menurut (Yuwono, dkk., 2006:39) proses pembelajaran dan pertumbuhan bersumber dari SDM, sistem, serta prosedur organisasi. Dalam perspektif ini juga masuk pelatihan pegawai dan budaya perusahaan yang berhubungan dengan perbaikan individu serta organisasi. Dalam perspektif ini, perusahaan melihat tolak 
E-Jurnal Manajemen Unud, Vol. -, No. -,2018:

ukur seperti employee capabilities, information system capabilities, motivation, empowerment, and alignment.

\section{METODE PENELITIAN}

Penelitian ini merupakan jenis penelitian kuantitatif yang bersifat deskriptif, yang dimana penelitian ini bertujuan untuk mencari tahu mengenai kinerja supply chain management di PT. Alove Bali IND.

Jenis data yang digunakan dalam penelitian ini adalah data kualitatif meliputi atatan keuangan dan index penjualan dan data kuantitatif dalam penelitian ini, meliputi pendapat manajer, distributor dan karyawan terhadap pernyataan yang terdapat didalam metrik kinerja yang digunakan.

Sumber data yang digunakan dalam penelitian ini adalah data primer yang langsung dikumpulkan dari sumber pertamanya yaitu jawaban responden terhadap pernyataan kuisioner yang dikumpulkan dari para manajer, distributor dan karywan PT. Alove Bali. Data sekunder yang digunakan dalam penelitian diperoleh dari hasil penelitian, jurnal, internet, artikel-artikel dan buku-buku teks yang mendukung..

Penelitian ini memiliki variabel yakni kinerja perspektif keuangan, kinerja perspektif pelanggan, dan kineja perspektif pembelajaan. Populasi dalam penelitian ini adalah seluruh manajer yang berjumlah 4 orang untuk perspektif bisnis internal serta perspektif pertumbuhan dan pembelajaran , 5 distributor untuk perspektif pelanggan, dan 16 karyawan untuk perspektif bisnis internal yang berada di PT. Alove Bali IND. Metode pengumpulan data menggunakan tiga metode yakni metode wawancara kepada para manajer, distributor dan karyawan perusahaan yang berkompeten yang 
berhubungan dengan penelitian, seperti gambaran umum PT. Alove Bali, bidang usaha atau produksi, keadaan manajemen yang berhubungan dengan keputusan strategis perusahaan, lalu metode observasi dengan dua langkah yakni observasi lapangan untuk mengukur variabel yang terkait dalam kinerja supply chain. Kedua, observasi terhadap data historis perusahaan. Selanjutnya adalah metode kuesioner dengan langsung diantarkan kepada sasaran responden ke lokasi penelitian yakni PT. Alove Bali. Kuesioner yang di sebar berupa daftar pertanyaan dan pernyataan mengenai metrik yang mengukur kinerja supply chain management pada PT. Alove Bali.

Instrumen ini diuji validitas dan reliabilitasnya sebelum kuesioner disebarkan kepada responden. Pada uji validitas dapat dilakukan dengan menilai instrumen yang diisi oleh responden, kemudian masing-masing pernyataan dihitung dengan teknik korelasi Product Moment. Variabel dikatakan valid apabila koefisien korelasi lebih besar dari 0,30 yang merupakan nilai pembanding minimal untuk mendapatkan korelasi yang valid (Sugiyono, 2014:148). Untuk mengukur reabilitas instrumen dalam penelitian ini adalah dengan Cronbach Alpha $(\alpha)$. Kuesioner dapat dikatakan reliabel atau handal apabila jawaban atas pertanyaan yang diberikan adalah konsisten atau dengan kata lain instrumen tersebut stabil dari waktu ke waktu (Ghozali, 2013:47). Untuk mengukur reabilitas instrumen dalam penelitian ini adalah dengan Cronbach Alpha $(\alpha)$. Suatu variabel dikatakan reliabel jika memberikan nilai Cronbach Alpha $(\alpha)$ $>$ 0,60 (Ghozali, 2013:47). 
E-Jurnal Manajemen Unud, Vol. -, No. -,2018:

\section{HASIL DAN PEMBAHASAN}

Jumlah responden dalam penelitian ini adalah 25 orang. Responden dalam penelitian memiliki kriteria yaitu orang-orang yang mengetahui mengenai kinerja perusahaan serta yang terjun langsung dalam proses produksi seperti manajer, distributor dan karyawan PT. Alove Bali IND. Secara rinci profil responden disajikan dalam Tabel 1 sebagai berikut.

Tabel 1.

Profil Responden

\begin{tabular}{|c|c|c|c|c|}
\hline No & Kriteria & & Jumlah Responden & Persentase \\
\hline \multirow[t]{3}{*}{1} & Jenis Kelamin & Laki-laki & 21 & $84 \%$ \\
\hline & & Perempuan & 4 & $16 \%$ \\
\hline & & Total & 25 & \\
\hline \multirow[t]{6}{*}{2} & Umur & Dibawah 20 tahun & 1 & $4 \%$ \\
\hline & & 20-29 tahun & 2 & $8 \%$ \\
\hline & & 30-39 tahun & 11 & $44 \%$ \\
\hline & & 40-49 tahun & 9 & $36 \%$ \\
\hline & & $>49$ tahun & 2 & $8 \%$ \\
\hline & & Total & 25 & \\
\hline \multirow[t]{5}{*}{4} & Tingkat Pendidikan & SD & 1 & $4 \%$ \\
\hline & & SMP & 4 & $16 \%$ \\
\hline & & SMA & 16 & $64 \%$ \\
\hline & & Sarjana & 4 & $16 \%$ \\
\hline & & Total & 25 & \\
\hline
\end{tabular}

Sumber :Data primer yang diolah, 2017 
Tabel 2.

Hasil Uji Validitas

\begin{tabular}{|c|c|c|c|c|}
\hline No & Variabel & Indikator & $\begin{array}{c}\text { Koefisien } \\
\text { Korelasi }\end{array}$ & Keterangan \\
\hline \multirow{5}{*}{1} & \multirow{5}{*}{$\begin{array}{l}\text { Perspektif } \\
\text { Pelanggan }\end{array}$} & Sales index & 1,000 & Valid \\
\hline & & Complaint quota & 1,000 & Valid \\
\hline & & Persetujuan awal & 1,000 & Valid \\
\hline & & Penilaian Pelayanan & 1,000 & Valid \\
\hline & & Sharing Information & 1,000 & Valid \\
\hline \multirow{3}{*}{2} & \multirow{3}{*}{$\begin{array}{l}\text { Perspektif Bisnis } \\
\text { Internal }\end{array}$} & Availibility & 0,880 & Valid \\
\hline & & Forecast Accuracy & 0,827 & Valid \\
\hline & & Lead Time Improvment & 0,813 & Valid \\
\hline \multirow{5}{*}{3} & \multirow{5}{*}{$\begin{array}{c}\text { Perspektif } \\
\text { Pembelajaran } \\
\text { Dan } \\
\text { Pertumbuhan }\end{array}$} & Kualitas Informasi & 0,929 & Valid \\
\hline & & Penggunaan Teknologi & 0,989 & Valid \\
\hline & & Investasi dalam bidang teknologi & 0,911 & Valid \\
\hline & & Total training related processes & 0,843 & Valid \\
\hline & & Total training related to customer & 0,989 & Valid \\
\hline
\end{tabular}

Sumber: Data Diolah, 2017

Berdasarkan hasil olah data yang ditunjukkan pada Tabel 2 dapat dilihat bahwa nilai koefisien korelasi dari masing-masing indikator menunjukkan nilai yang lebih besar dari 0,3 ( $\mathrm{r} \geq 0,3)$, hal ini berarti bahwa semua instrumen yang digunakan adalah valid.

Tabel 3.

Hasil Uji Reliabilitas

\begin{tabular}{clcc}
\hline No & \multicolumn{1}{c}{ Variabel } & $\begin{array}{c}\text { Cronbach } \\
\text { alpha }\end{array}$ & Keterangan \\
\hline 1 & Perspektif Pelanggan & 1,000 & Reliabel \\
2 & Perspektif Bisnis Internal & 0,760 & Reliabel \\
3 & Perspektif Pembelajaran dan & 0,954 & Reliabel \\
& Pertumbuhan & & \\
\hline \multicolumn{2}{l}{ Sumber: Data Diolah, 2017 }
\end{tabular}

Tabel 3 menunjukkan bahwa seluruh variabel yang digunakan dalam penelitian ini telah mampu memenuhi syarat konsistensi dan keandalan data. Dalam uji reliablitas di atas, keseluruhan variabel memiliki nilai cronbach alpha yang lebih besar dari 0,6. 
E-Jurnal Manajemen Unud, Vol. -, No. -,2018:

Dapat disimpulkan bahwa seluruh indikator variabel dalam penelitian ini adalah reliabel, sehingga dapat digunakan sebagai instrumen penelitian

\section{Penilaian cash conversion cycle PT. Alove Bali IND}

Berikut disajikan gambar Penilaian Cash Cycle PT. Aloeve Bali IND.

\begin{tabular}{|c|c|c|c|c|c|c|}
\hline \multirow{2}{*}{ Keterangan } & \multicolumn{6}{|c|}{ Tabup } \\
\hline & 2611 & $2 \Leftrightarrow 12$ & 2613 & $26 ! 4$ & 2615 & 2016 \\
\hline \multirow[b]{2}{*}{ Intentory } & \multicolumn{6}{|c|}{ Dalam Rupiah } \\
\hline & \multicolumn{6}{|c|}{$\frac{\text { Dalam kupala }}{16335540717 \quad 17558700030}$} \\
\hline $\begin{array}{l}\text { Account } \\
\text { receireble }\end{array}$ & 957095038 & 225874355 & 800781239 & 965195970 & 1267303026 & 9.587 .151 .772 \\
\hline \multirow{5}{*}{$\begin{array}{l}\text { Account } \\
\text { Payable } \\
\text { HPP } \\
\text { Sales }\end{array}$} & & & & & & \\
\hline & 36.275 .141 .245 & 38.046 .558 .545 & 38.433 .502 .796 & 39.828 .502 .796 & 40.171 .436 .358 & 40.923 .163 .264 \\
\hline & 5.315 .907 .280 & 60.947 .074 & 3.385 .396 .641 & 151.462 .478 & 8.322 .794 .626 & 687.068 .074 \\
\hline & 1.383 .648 .002 & 292.090 .910 & 1.977 .884 .391 & 387.812 .029 & 1.199 .980 .120 & 1.370 .167 .803 \\
\hline & \multicolumn{6}{|c|}{ Dalam Hari } \\
\hline \multicolumn{7}{|l|}{ Daj's } \\
\hline $\begin{array}{l}\text { Inientory } \\
\text { Day's }\end{array}$ & 1159.09 & 110415.03 & 1761.23 & 42313.84 & 468.55 & 1853.89 \\
\hline $\begin{array}{c}\text { receireble } \\
\text { Day's }\end{array}$ & 252.48 & 282.26 & 149.44 & 908.42 & 385.48 & 929.63 \\
\hline Payable & 2490.72 & 227853.33 & 4143.75 & 95980.23 & 1761.74 & 21740.14 \\
\hline \multicolumn{7}{|l|}{ Contersion } \\
\hline Cycle & -1079.15 & -117156.05 & .2233 .08 & .52757 .97 & .907 .71 & -18956.62 \\
\hline
\end{tabular}

Gambar 1. Penilaian Cash Cycle PT. Aloeve Bali IND

Sumber : Data diolah, 2017

Menurut Benardi dan Minarnita (2012), Angka negatif pada nilai CCC tersebut menunjukkan bahwa perusahaan telah mengelola modal kerjanya dengan agresif yang berdampak mempercepat perputaran persediaan dan piutang dagang dan di pihak lain memilih menunda pembayaran hutang dagang sampai dengan jangka waktu yang masih tercakup di dalam jangka waktu kredi yang dapat diterima oleh vendor tetapi lebih disukai oleh perusahaan. Dapat dilihat pada analisis cash conversion cycle, Days Receivable Days pada tahun 2011 sebesar 252,48 hari menunjukkan bahwa piutang baru dapat tertagih dalam jangkan waktu 252,48 hari dan terus meningkat hingga 
mencapai 929.63 hari pada tahun 2016. Waktu tersebut tergolong sangatlah lama, karena perusahaan memiliki standard bahwa piutang harus tertagih dalam jangka waktu 4 sampai 5 bulan, sehingga jelas hal ini berdampak pada pemasukan dari arus kas perusahaan.

Apabila melihat nilai dari cash conversion cycle perusahaan PT. Alove IND memiliki angka yang negatif yaitu $(-1079,15)$ hari pada tahun 2011 dan terus meningkat hingga mencapai nilai $(-18956,62)$ hari pada tahun 2016 ini menunjukkan bahwa perusahaan masih belum memiliki kas yang cukup untuk mendanai seluruh aktivitas perusahaan secara optimal inui memperlihatkan kondisi yang kurang baik, karena perusahaan terlalu banyak menggunakan hutang dalam kegiatan operasionalnya namun tidak diimbangi dengan hasil penjualan perusahaan.

\section{Sales Growth}

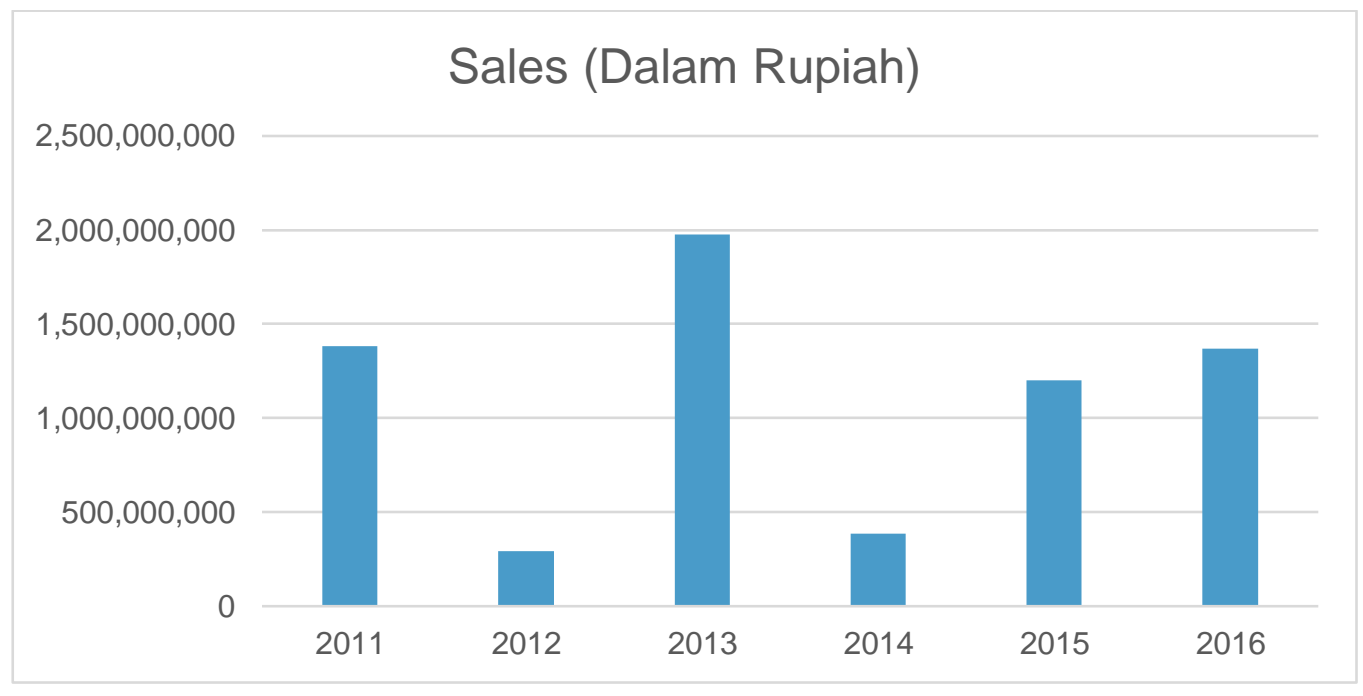

Gambar 2. Penilaian Cash Cycle PT. Aloeve Bali IND

Sumber : Data diolah, 2017 
E-Jurnal Manajemen Unud, Vol. -, No. -,2018:

Jika dilihat dari grafik di atas penjualan pada PT. Alove Bali Ind sangatlah fluktuaktif. Pada tahun 2012 perusahaan mengalami penjualan terendah dikarenakan pada tahun tersebut perusahaan sama sekali tidak mendapatkan pesanan dari luar begitu pula pada tahun 2014 hasil export perusahaan terbilang sedikit hanya mencapai Rp 344.974.364 dibandingkan dengan tahun 2013 yang merupakan penjualan tertinggi perusahaan ini dikarenakan hasil export perusahaan pada tahun tersebut sebesar Rp 1.919.690.488,00 dapat disimpulkan bahwa pertumbuhan penjualan PT. Alove Bali IND sangat dipengaruhi dari hasil export perusahaan

\section{Perspektif Pelanggan}

\section{Tabel 4.}

Penilaian Responden terhadap variabel Perspektif Pelanggan

\begin{tabular}{|c|c|c|c|c|c|c|c|c|}
\hline \multirow[t]{2}{*}{ Indikator } & \multicolumn{5}{|c|}{$\begin{array}{l}\text { Klasifikasi jawaban } \\
\text { responden (orang) }\end{array}$} & \multirow[t]{2}{*}{ Total Skor } & \multirow{2}{*}{$\begin{array}{l}\text { Rata-Rata } \\
\text { Skor }\end{array}$} & \multirow[t]{2}{*}{ Keterangan } \\
\hline & 1 & 2 & 3 & 4 & 5 & & & \\
\hline Sales index $\left(\mathrm{X}_{2.1}\right)$ & 0 & 0 & 3 & 2 & 0 & 17 & 3.40 & Baik \\
\hline Complaint quota $\left(\mathrm{X}_{2.2}\right)$ & 0 & 0 & 0 & 3 & 2 & 22 & 4.40 & Sangat baik \\
\hline Persetujuan awal $\left(\mathrm{X}_{2.3}\right)$ & 0 & 0 & 0 & 3 & 2 & 22 & 4.40 & Sangat baik \\
\hline Penilaian Pelayanan $\left(\mathrm{X}_{2.4}\right)$ & 0 & 0 & 0 & 3 & 2 & 22 & 4.40 & Sangat baik \\
\hline Sharing Information $\left(\mathrm{X}_{3.3}\right)$ & 0 & 0 & 0 & 3 & 2 & 22 & 4.40 & Sangat baik \\
\hline Jumlah & & & & & & 104 & 4.20 & Sangat baik \\
\hline
\end{tabular}

Sumber: Data Diolah, 2017

Responden dengan jawaban tertinggi ditunjukkan pada pernyataan tentang

Penilaian Pelayanan atau penilaian yang dilakukan oleh perusahaan atas pelayanan yang dilakukan oleh perusahaan mitra dan sebaliknya, complaint quota atau bagaimana cara perusahaan dalam mengelola kepuasan dan komplain yang dirasakan oleh perusahaan mitra, persetujuan awal kesepakatan awal untuk memulai kerjasama yang berisi keterikatan antar perusahaan mitra serta kewajiban dalam kerjasama dan sharing information atau adanya sharing dalam hal informasi dengan skor rata-rata yang sama 
yaitu sebesar 4.40. Pernyataan tersebut, 2 responden menjawab sangat setuju dan 3 responden menjawab setuju. Skor rata-rata terendah didapat dengan skor rata-rata 3.40 pada pernyataan terkait sales index atau volume penjualan setiap bulannya. Pernyataan tersebut, 2 responden menjawab setuju dan 3 responden menjawab cukup setuju.

Melihat data dari keseluruhan variabel Perspektif Pelanggan, dapat ditentukan rata-rata total dengan skor adalah sebesar 4.20, dan ditambah dengan hasil wawancara pada indikator sales index dapat dilihat dalam perspektif keuangan yang menunjukkan tingkat pertumbuhan penjualan setiap tahunnya yang mengalami pasang surut. Untuk indikator Complaint quota, penilaian pelayanan dan Sharing Information menurut hasil wawancara peneliti terhadap agen, agen selalu memberikan informasi mengenai keluhan yang dirasakan oleh pelanggan sebagai contoh pada awalnya produk pupuk ini dijual seharga $\mathrm{Rp}$ 42.000,00 namun karena kemampuan daya beli petani yang rendah dan dan akhirnya perusahaan pun menurunkan harganya menjadi Rp 25.000,00 ini membuktikan perusahaan selalu tanggap dalam hal menangani komplain pelanggan begitu juga dalam hal pelayanan dan untuk indikator persetujuan awal atau dalam hal ini adanya kontrak didalam melakukan kerjasama memang benar perusahaan selalu menggunakan kontrak didalam kerjasamanya terhadap agen, maka dapat dinyatakan bahwa secara umum responden memiliki persepsi baik tehadap kinerja dalam perspektif pelanggan pada PT. Alove Bali IND. 


\section{Perspektif Bisnis Internal}

\section{Tabel 5.}

Penilaian Responden terhadap variabel Perspektif Bisnis Internal

\begin{tabular}{|c|c|c|c|c|c|c|c|c|}
\hline \multirow[t]{2}{*}{ Indikator } & \multicolumn{5}{|c|}{$\begin{array}{l}\text { Klasifikasi jawaban } \\
\text { responden (orang) }\end{array}$} & \multirow[t]{2}{*}{ Total Skor } & \multirow[t]{2}{*}{$\begin{array}{l}\text { Rata-Rata } \\
\text { Skor }\end{array}$} & \multirow[t]{2}{*}{ Keterangan } \\
\hline & 1 & 2 & 3 & 4 & 5 & & & \\
\hline Availibility $\left(\mathrm{X}_{3.1}\right)$ & 0 & 0 & 0 & 3 & 17 & 97 & 4.85 & Sangat baik \\
\hline Forecast accuracy $\left(\mathrm{X}_{3.2}\right)$ & 0 & 0 & 0 & 8 & 12 & 92 & 4.60 & Sangat baik \\
\hline Lead time improvment $\left(\mathrm{X}_{3.3}\right)$ & 0 & 0 & 0 & 2 & 18 & 98 & 4.90 & Sangat baik \\
\hline Jumlah & & & & & & 287 & 4.78 & Sangat baik \\
\hline
\end{tabular}

Responden dengan jawaban tertinggi ditunjukkan pada pernyataan tentang Lead time improvment dengan skor rata-rata 4.90. Pernyataan tersebut, 18 responden menjawab sangat setuju dan 2 responden menjawab setuju. Skor rata-rata terendah didapat dengan skor rata-rata 4.60 pada pernyataan terkait Forecast accuracy atau akurasi dalam peramalan. Pernyataan tersebut, 12 responden menjawab sangat setuju dan 8 responden menjawab setuju. Pernyataan terkait availability atau ketersediaan barang yang berhubungan antara barang yang ada di gudang dan pemesanan barang oleh pelanggan, 17 responden menjawab sangat setuju dan 3 responden menjawab setuju.

Melihat data dari keseluruhan variabel Perspektif Bisnis Internal, dapat ditentukan rata-rata total dengan skor adalah sebesar 4.78, dan ditambah dengan hasil wawancara pada indikator availability, PT Alove Bali IND tentu dapat memenuhi permintaan pelanggan hal ini dapat dilihat dari perspektif keuangan yang menunjukkan bahwa ketersediaan barang di gudang selalu bertambah setiap tahunnya, untuk indikator forecast accuracy atau akurasi peramalan yang seharusnya berkaitan erat 
Dannis Tanaka dan I Nyoman Nurcaya, Analisis Kinerja...

dengan perencanaan produksi selanjutnya, namun disini perusahaan tidak menargetkan didalam hal produksi namun menargetkan bagaimana perusahaan harus mampu memenuhi permintaan setiap pelanggan dan yang terkahir indikator lead time improvement atau waktu tunggu antara proses pemesanan yang dilakukan pelanggan hingga pengiriman produk jadi akhir ke tangan pelanggan didalam hasil wawancara peneliti pada beberapa agen, perusahaan selalu mengirimkan produknya tepat waktu dan tidak pernah terjadi keterlambatan, maka dapat dinyatakan bahwa secara umum responden memiliki persepsi sangat baik tehadap kinerja Bisnis Internal pada PT. Alove Bali IND.

\section{Perspektif Pembelajaran Dan Pertumbuhan}

Tabel 6.

Penilaian Responden terhadap Perspektif Pembelajaran dan Pertumbuhan

\begin{tabular}{|c|c|c|c|c|c|c|c|c|}
\hline \multirow[t]{2}{*}{ Indikator } & \multicolumn{5}{|c|}{$\begin{array}{l}\text { Klasifikasi jawaban } \\
\text { responden (orang) }\end{array}$} & \multirow{2}{*}{$\begin{array}{l}\text { Total } \\
\text { Skor }\end{array}$} & \multirow{2}{*}{$\begin{array}{c}\text { Rata-Rata } \\
\text { Skor }\end{array}$} & \multirow[t]{2}{*}{ Keterangan } \\
\hline & 1 & 2 & 3 & 4 & 5 & & & \\
\hline kualitas informasi $\left(\mathrm{X}_{4.1}\right)$ & 0 & 0 & 0 & 7 & 13 & 93 & 4.65 & Sangat baik \\
\hline $\begin{array}{l}\text { Penggunaan teknologi } \\
\left(\mathrm{X}_{4.2}\right)\end{array}$ & 0 & 0 & 1 & 6 & 13 & 92 & 4.60 & Sangat baik \\
\hline $\begin{array}{l}\text { Investasi dalam bidang } \\
\text { teknologi dan informasi } \\
\left(\mathrm{X}_{4.3}\right)\end{array}$ & 0 & 1 & 0 & 8 & 11 & 89 & 4.45 & Sangat baik \\
\hline $\begin{array}{l}\text { Total training related } \\
\text { processes }\left(\mathrm{X}_{4.4}\right)\end{array}$ & 0 & 0 & 0 & 5 & 15 & 95 & 4.75 & Sangat baik \\
\hline $\begin{array}{l}\text { Total training related to } \\
\text { customer service }\left(\mathrm{X}_{4.5}\right)\end{array}$ & 0 & 0 & 1 & 6 & 13 & 92 & 4.60 & Sangat baik \\
\hline Jur & & & & & & 461 & 4.61 & Sangat baik \\
\hline
\end{tabular}

Sumber: Data Diolah, 2017

Responden dengan jawaban tertinggi ditunjukkan pada pernyataan tentang

Total training related processes atau pelatihan terhadap karyawan mengenai proses

produksi yang terjadi pada perusahaan dengan skor rata-rata 4.75. Pernyataan

tersebut, 15 responden menjawab sangat setuju dan 5 responden menjawab setuju. 
E-Jurnal Manajemen Unud, Vol. -, No. -,2018:

Skor rata-rata terendah didapat dengan skor rata-rata 4.45 pada pernyataan terkait Investasi dalam bidang teknologi dan informasi. Pernyataan tersebut, 11 responden menjawab sangat setuju, 8 responden menjawab setuju dan 1 responden menjawab tidak setuju. Pernyataan terkait kualitas informasi, 13 responden menjawab sangat setuju dan 7 responden menjawab setuju. Pertanyaan terkait penggunaan teknologi, 13 responden menjawab sangat setuju, 6 responden menjawab setuju dan 1 responden menjawab cukup setuju. Dan pertanyaan terakhir terkait Total training related to customer atau pelatihan terhadap karyawan mengenai bagaimana cara melayani pelanggan dengan baik, 13 responden menjawab sangat setuju, 6 responden menjawab setuju dan 1 responden menjawab cukup setuju

Melihat data dari keseluruhan variabel Perspektif Pembelajaran Dan Pertumbuhan, dapat ditentukan rata-rata total dengan skor adalah sebesar 4.61, menurut hasil wawancara peniliti untuk indikator kualitas informasi terkait dengan sebuah keakuratan informasi, perusahaan sudah memberikan informasi terkait produknya seperti dalam hal pemakaian yang sudah dicantumkan dalam label produknya. Dan untuk indikator penggunaan teknologi maupun investasi dalam hal teknologi dan informasi dari survei lapangan memang benar perusahaan sudah menggunakan teknologi didalam memproduksi produknya dan juga melakukan investasi dalam hal teknologi. Dan untuk indikator pelatihan karyawaan, perusahaan selalu berfokus pada pelatihan dalam hal produksi dibandingkan dengan hal pelayanan terhadap pelanggan ini terlihat dari Tabel 6 bahwa rata-rata nilai responden terhadap Total training related processes lebih tinggi dibandingkan 
rata-rata nilai Total training related to customer service, maka dapat dinyatakan bahwa secara umum responden memiliki persepsi sangat baik tehadap kinerja Pertumbuhan Dan Pembelajaran pada PT. Alove Bali IND karena total rata-rata nilai responden dalam perpspektif ini adalah sebesar 4,61 yang masuk kategori sangat baik.

\section{Implikasi Hasil Penelitian}

Berdasarkan hasil penelitian yang disimpulkan di atas bahwa secara keseluruhan Pengukuran kinerja supply chain management PT. Alove Bali IND dengan menggunakan metode balanced scorecard adalah : 1) Pengukuran kinerja PT. Alove Bali IND diukur dengan perspektif keuangan masih dirasa kurang baik dan memperlihatkan kondisi yang fluktuatif dari tahun 2011 hingga tahun 2014 dan untuk memutar modalnya perusahaan masih sangat tergantung pada pinjaman dari owner.Hal ini perlu menjadi perhatian perusahaan agar kedepannya lebih meingkatkan penjualannya khususnya pada penjualan local, 2) Dari Perspektif pelanggan sendiri menunjukkan hasil yang baik, ini terlihat dari penilaian responden terhadap indikator pada perspektif ini namun perusahaan harus tetap menjaga kualitas pelayanan agar terus ditingkatkan sehingga pelanggan akan terus merasa nyaman dan tingkat kepercayaan terhadap perusahaan pun semakin tinggi, 3) Penilaian kinerja bisnis internal dapat dikatakan sangat baik, namun pada hasil kuisioner indikator forecast accuracy memiliki nilai yang paling rendah, indikator ini berkaitan dengan pencapaian penjualan dari target yang telah ditentukan. PT. Alove Bali IND sendiri tidak memiliki target yang harus dicapai didalam penjualannya namun target dari PT. Alove Bali IND 
E-Jurnal Manajemen Unud, Vol. -, No. -,2018:

sendiri adalah bagaimana permintaan pelanggan harus selalu dapat dipenuhi, jadi perusahaan juga harus memulai untuk membuat target di dalam penjualannya, 4) Penilaian kinerja pertumbuhan dan pembelajaran dapat dikatakan sangat baik, ini terlihat dari hasil jawaban responden terhadap setiap indikator. Namun perusahaan perlu memperhatikan pada indikator pelatihan terhadap karyawan dalam hal melayani konsumen karena menurut wawancara peneliti perusahaan belum intensif memeberikan pelatihan karyawan khususnya pada pelayanan konsumen. Karena dengan adanya pelatihan karyawan terhadap bagaimana cara melayani konsumen tentu akan meningkatkan penjualan perusahaan sendiri, 5) Penerapan Balanced Scorecard dapat dijadikan masukan, bahan pertimbangan, serta referensi dalam pengukur kinerja Supply Chain Management suatu perusahaan.

\section{SIMPULAN DAN SARAN}

Berdasarkan pembahasan hasil penelitian yang telah dilakukan, maka dapat diambil kesimpulan sebagai berikut:

Pada perspektif keuangan, kinerja PT. Alove Bali IND dilihat dari perspektif keuangan dengan menggunakan metode balanced scorecard yang dilihat dari dua indikator yaitu Cash To Cash Cycle dan Sales Growth menunjukkan bahwa penilaian kinerja keuangan PT. Alove Bali IND kurang Baik. Hal ini terlihat dari masih adanya fluktuasi pada pertumbuhan penjualan dan PT. Alove Bali IND didalam memutar modalnya masih sangat tergantung pada hutang yang diberikan oleh owner.

Pada perspektif pelanggan, kinerja PT. Alove Bali IND dari perspektif pelanggan dapat dikatakan baik ini dibuktikan dari hasil rata-rata jawaban responden yang 
mencapai nilai rata-rata keseluruhan sebesar 4.20. dalam perspektif pelanggan untuk mengukur Supply Chain Management yang paling terpenting adalah dalam hal kualitas pelayanan, adanya kontrok kerjasama, berbagi informasi dan bagaimana menangani keluhan dari pelanggan dan 4 indikator tersebut mendapat nilai rata-rata yang paling tinggi dibandingkan indikator yang lain ini membuktikan bahwa kualitas pelayanan PT. Alove Bali IND sangat baik.

Pada perspektif bisnis internal, kinerja PT. Alove Bali IND dilihat dari perspektif bisnis internal dapat dikatakan sangat baik karena rata-rata hasil jawaban responden adalah sebesar 4.78 ini membuktikan bahwa ketersediaan produk di gudang selalu mampu memenuhi permintaan pelanggan, dan untuk target perusahaan pun sudah dapat dicapai dan perusahaan mampu membuat produknya sampai di tangan pelanggan tepat waktu.

Pada perspektif pertumbuhan dan pembelajaran, kinerja PT. Alove Bali IND dilihat dari perspektif pertumbuhan dan pembelajaran dapat dikatakan sangat baik karena rata-rata hasil jawaban responden adalah sebesar 4.61. ini mebuktikan bahwa dari kelima indikator perspektif ini perusahaan sudah melakukannya, baik itu dalam hal kualitas informasi, penggunaan teknologi dalam produksinya, melakukan investasi dalam bidang teknologi, dan melakukan pelatihan karyawan baik dalam hal produksi maupun dalam hal melayani pelanggan.

Berdasarkan kesimpulan penelitian dan implikasi hasil penelitian yang dikemukakan di atas, maka saran yang diharapkan dapat berguna bagi semua pihak 
antara lain:

Diharapkan PT. Alove Bali IND lebih meningkatkan pada penjualan lokalnya, membuat target penjualan setiap tahunnya dan juga lebih intensif memberikan pelatihan karyawan dalam hal melayani pelanggan, kepada peneliti selanjutnya diharapkan objek penelitian selanjutnya lebih dari satu sehingga dapat membandingkan kinerja beberapa perusahaan yang sejenis, diharapkan mampu menambahkan indikator pengukuran kinerja supply chain management dalam perspektif balanced scorecard, dan diharapkan mampu meberikan tolak ukur dalam penilaian kinerja supply chain management untuk setiap indikator pada perspektif balanced scorecard.

\section{REFERENSI}

Ade Mukhlis Afif, Dwi K., dan Alex Saleh. 2015. Usulan Perancangan Pengukuran Kinerja Rantai Pasok Menggunakan Metode Balanced Scorecard Pada Bengkel Otomotif X. Jurnal. Reka Integra Itenas. ISSN 2338-5081, 3 (2), hal ${ }^{1}$. 104-114.

Andrew Pateman, 2008. Lingking Strategy to Operation: Six Stage to Execution Bussines Performance Management Magazine

Ariani, Desi \& Munas, Bambang.2013. Analisis Pengaruh Supply Chain Management Terhadap kinerja Kinerja Perusahaan (Studi Pada Industri Kecil dan Menengah Makanan Olahan Khas Padang Sumatera Barat). Jurnal Studi Manajemen dan Organisasi, 10(2), hal. 132-141

Arik A.G., (2006), A balanced scorecard model for the performance measurement of enterprise planning implementation Graduate Thesis , Middle East Technical University

Aziz, Rasyadan Tanrizi dan Dwiyanto, Bambang Munas. 2017. Analisis Pengaruh Long Term Relationship, Information Sharing, Coopeation, Integration 
Process Terhadap Kinerja supply Chain Management (Studi Pada UKM Kota Gresik). Diponegoro journal of management. 6 (4), hal. 1-12

Bastian, Indra. 2009. Akuntansi Sektor Publik Di Indonesia. Edisi Revisi. Yogyakarta: BPFE

Benardi, Barni \& Bakara, Minarnita Y. Verawati. 2012. Mengukur Cash Conversion Cycle Perusahaan Terbuka Operator Telekomunikasi Seluler Di Indonesia Dalam Keterkaitannya Dengan Kinerja Pengelolaan Modal Kerja. Incom Tech, Jurnal Telekomunikasi Dan Komputer. 3 (1), hal. 27-48

Bhagwat, R., \& Sharma, M. K. (2007). Performance measurement of supply chain management: A balanced scorecard approach. Computers and Industrial Engineering, 53 (1), pp. 43-62.

Brewer, P. C., \& Speh, T. W. (2000). Using the Blanced Scorecard To Measure Supply Chain Perormance. Journal Of Businees Logistic, 21 (1), pp. 75-93.

D’Avanzo, R., \& Lewinski, H. von. (2003). The Link Between Supply Chain and Financial Performance. Supply Chain Management Review, 7 (6), pp. 4047.

Dodangh, Javad, Majid Mojehad and Vahid Nasehifar. 2010. Ranking of Strategic Plans In Balanced Scorecard by Using Electric Method. International Journal of Innovation. management and Technology , 1 (3), pp. 269-274

Ellinger, A. E., Natarajarathinam, M., Adams, F. G., Brian Gray, J., Hofman, D., \& O’Marah, K. (2011). Supply chain management competency and firm financial success. Journal of Business Logistics, 32(3), pp. 214-226.

Geovana, Rosella Selvilita. 2015. Pengaruh Growth Sales, Profitabilitas, Operating Leverage, Dan Tax Rate Terhadap Kebijakan Hutang. Jurnal \& Ilmu Riset Akuntansi, 4 (4), hal. 1-15

Ghosh, Samir. 2006. Measurenment of Corporate Performanced Through Balanced Scorecard: An Overview.

Ghozali, Imam. 2013. Aplikasi Analisis Multivariate dengan Program SPSS. Edisi Keempat, Penerbit Universitas Diponogoro, hal.143-125.

Gunasekaran, A., Patel, C., \& Tirtiroglu, E. 2001. Performance Measures and Metrics In a Supply Chain Environment. International Journal of Production and Operation Management. 21 (1/2), pp. 71-78 
E-Jurnal Manajemen Unud, Vol. -, No. -,2018:

Hansen, Don R. dan Maryanne M. Mowen. 2009. Akuntansi Manajerial, Jakarta: Salemba Empat

Heizer, J. dan B. Render. 2005. Manajemen Operasi (Terjemahan). Jakarta: Salemba Empat

Jogiyanto. 2007. Model Kesuksesan Sistem Teknologi Informasi. Penerbit Andi Yogyakarta

Jovanovic, Jelena. 2009. Balanced Scorecard Model Evaluation: The Case Of AD Barska Plovidba. Montenegero: Faculty of Mechanichal Engineering.

Kaplan, R.S. and Norton, D.P. (1996), "Using the balanced scorecard as a strategic management system", Harvard Business Review, 74 (1), pp. 75-85.

Lestari, Sri. 2015. Pengelolaan Diversitas Karyawan Dalam Membangun Keunggulan Kompetitif. Jurnal Fokus Bisnis. 14 (1), hal. 35-59

Mulyadi \& Jhonny S. 2001. Sistem dan Pengendalian Manajemen : Sistem Pelipatgandaan Kinerja. Yogyakarta: Aditya Media

Mulyadi. 2001. Balanced scorecard: Alat Manajemen Kontemporer untuk Pelipatgandaan Kinerja Keuangan Perusahaan. Edisi ke-2. Jakarta: Salemba Empat

Pertiwi, Adela Anggun., Kurniawan, Dwi., \& Fitria, Lisye. 2016. Perancangan Sistem Pengukuran Kinerja Kolaborasi Rantai Pasokan Dengan Menggunakan Balanced Scorecard. Jurnal Online Institut Teknologi Nasional. 4 (1), hal. 111

Pratiwi, Yoshi Trias \& Rodhiyah. Strategy Map Balanced Scorecard: Sistem Manajemen Untuk Implementasi Strategi Perusahaan (Studi Kasus PT Erratisa Purnama). Jurnal Buletin Studi Ekonomi. 20 (1), h. 23-42

Pujawan, I Nyoman \& Er, Mahendrawati. 2010. Supply Chain Management edisi 2. Institut Teknologi Sepuluh Nopember: Guna Widya

R.Rahmy. 2015. Pengaruh Profitabilitas, Financial Leverage, Sales Growth Dan Aktivitas Terhadap Financial Distrees (Studi Empiris Pada Perusahaan Manufaktur Yang Terdaftar Di BEI Tahun 2009-2012). Skripsi Universitas Negeri Padang

Rachbini, Widarto. 2016. Supply Chain Management Dan Kinerja Perusahaan. Jurnal Riset Manajemen dan Bisnis. 1 (1), hal. 23-30 
Rahmasari, Lisda.2011. Pengaruh Supply Chain Management Terhadap Kinerja Perusahaan Dan Keunggulan Bersaing (Studi Kasus Pada Industri Kreatif di Provinsi Jawa Timur). Majalah Ilmiah Informatika. 2 (3), hal. 89-103

Rakmawati, C. dan Mira. 2008. Analisis Faktor-Faktor Yang Mempengaruhi Struktur Modal pada Perusahaan Otomotif Yang Terdaftar Di BEI. Skripsi Universitas Islam Indonesia.

Ramanathan, U., dan Gunasekaran, A., dan Subramanian, N. 2011. Supply chain Collaboration Performance Metrics: A Conceptual Framework, Benchmarking: An International Journal 18 (6), pp. 856-872.

Rayno, \& Adityo, D. 2016. Efektivitas Kontrak Baku Dalam Mobilatas Bisnis (Perspektif Hukum Progresif). Mahkamah, 1 (1), hal. 111-129.

Ruslim, Tommy Setiawan, 2013. Analisis Pengaruh Supply Chain Magemnt Terhadap Loyalitas Pelanggan Journal of Industrial Engineering \& Management System. 6 (1), hal. 33-46

Shi, M., \& Yu, W. (2013). Supply chain management and financial performance: Literature review and future directions. International Journal of Operations \& Production Management. 33 (10), pp. 1283-1317

Sugiyono. 2014. Metode Penelitian Bisnis. Bandung: Alfabeta.

Sugiyono. 2016. Metode Penelitian Bisnis. Bandung: Alfabeta.

Suharto, Regina \& Devie 2013. Analisa Pengaruh Supply Chain Management terhadap Keunggulan Bersaing dan Kinerja Perusahaan. Jurnal Business Acounting Review. 1(2), hal. 1-1

Suzuki, S., Kitamura, S., \& Enkawa, T. (2009). The influence of market uncertainty on SCM competencies and managerial performance. Journal of Japan Industrial Management Association, 60 (2), pp. 69-76.

Syarief, Moch. Edman, dan Wilujeng, Ita Prihatining. 2009. Cash Conversion Cycle dan Hubungannya dengan Ukuran Perusahaan, Profitabilitas dan Manajemen Modal Kerja. Jurnal Ekonomi Bisnis, Nomor 1. hal. 61-69

Tansri, Ayu Begawan. 2012. Analisis Kinerja Dengan Pendekatan Balanced Scorecard Pada The Coffee Bean and Tea Leaf Cabang Bali. Skripsi. Fakultas Ekonomi Jurusan Akuntansi Universitas Udayana. Denpasar 
E-Jurnal Manajemen Unud, Vol. -, No. -,2018:

Thatte, A. A., Rao, S. S., \& Ragu-Nathan, T. S. (2013). Impact of SCM practices of a firm on supply chain responsiveness and competitive advantage of a firm. Journal of Applied Business Research, 29 (2), pp. 499-530.

Wagner, S. M., Grosse-Ruyken, P. T., \& Erhun, F. (2012). The link between supply chain fit and financial performance of the firm. Journal of Operations Management, 30 (4), pp. 340-353.

Wibowo, Setyo. 2006. Balanced dari Performance Measurenment Hingga Strategy Focused Organization.

Widyanto, Agus. 2012. Peran Supply Chain Management Dalam Sistem Produksi Dan Operasi Perusahaan. Jurnal Manajemen Bisnis. 16 (2): hal. 91-98

West, Lindy. 2009. The Balanced Scorecard As A Framework For Performance Management In The Non Profit Sector. University of Canberra

Yuwono, Sony, Sukarno, Edy dan Ichsan, Muhammad. 2006. Petunjuk Praktis Penysunan Balanced ScorecarMenuju Organisasi Yang Berfokus Pada Strategi. Jakarta: PT. Gramedia Pustaka Utama 